\title{
ANNALYSIS OF Pb, Cu AND Zn METAL CONTENTS IN RED CHUT-CHUT SNAIL (Cerithidea obtusa) AND SEDIMENT IN MENDOL ISLAND KUALA KAMPAR OF RIAU PROVINCE
}

\author{
Susi Sumanti ${ }^{*}$, Irvina Nurrachmi ${ }^{2}$, Yusni Ikhwan Siregar ${ }^{2}$ \\ ${ }^{1}$ Student of The Faculty of Fisheries And Marine Science University of Riau, Pekanbaru \\ ${ }^{2}$ Lecturer at the Faculty of Fisheries And Marine Science University Riau, Pekanbaru \\ *susisumanti1996@gmail.com
}

\begin{abstract}
The study was conducted in July 2018. Sampling of sedut snails (Cerithidea obtusa) which was carried out in the waters of Mendol Island, Kuala Kampar District, Pelalawan Regency was aimed to determine the differences in the content of $\mathrm{Pb}, \mathrm{Cu}$ and $\mathrm{Zn}$ between slugs and sediments and to know the consumption limits and the level of heavy metal pollution in the waters of Mendol Island. The method used in this study is the survey method. Sampling was determined using purposive sampling. The results of this study indicate the value of the metal content of $\mathrm{Pb}, \mathrm{Cu}$, and $\mathrm{Zn}$ in sedut snail highest at station 2, respectively: 9,2633 $\mu \mathrm{g} / \mathrm{g}, 72,040 \mu \mathrm{g} / \mathrm{g}, 111,748 \mu \mathrm{g} / \mathrm{g}$. Whereas for $\mathrm{Pb}, \mathrm{Cu}$, and $\mathrm{Zn}$ metals, the highest sediment was found at station 2, namely: $23.990 \mu \mathrm{g} / \mathrm{g}, 4.795 \mu \mathrm{g} / \mathrm{g}, 48.587 \mu \mathrm{g} / \mathrm{g}$ The results of linear regression analysis of $\mathrm{Pb}$ metal concentrations in snail meat showed negative results, and the concentration of $\mathrm{Zn}$ and $\mathrm{Cu}$ metals in snail meat showed positive results. namely $\mathrm{Pb}$ with a value of $14.1930 \mathrm{~kg} /$ week on $\mathrm{Zn}$ metal with a value of $111.7483 \mathrm{~kg} /$ week, while $\mathrm{Cu}$ metal at station 2 with a value of $72.0400 \mathrm{~kg} /$ week
\end{abstract}

Keyword: heavy metal, pollution, Cerithidea obtusa

\section{PENDAHULUAN}

Pulau Mendol atau yang dikenal dengan pulau Penyalai adalah pulau terbesar yang terletak di Kecamatan Kuala Kampar Kabupaten Pelalawan Provinsi Riau. Logam berat merupakan komponen alami yang terdapat di kulit bumi yang tidak dapat didegradasi ataupun dihancurkan.

Logam-logam berat umumnya bersifat toksik (racun) dan kebanyakan terdapat di air dalam bentuk ion. Tingkat pencemaran logam berat disebabkan oleh tumpahan minyak dari alat tranpotasi laut, pelabuhan dan tempat bersandarnya ponton. Adanya aktifitas tersebut diduga menambah kandungan logam berat di perairan tersebut di antaranya $\mathrm{Pb}, \mathrm{Cu}$ dan Zn Bahan pencemar ini sangat berbahaya karena mempunyai kecenderungan untuk terakumulasi dalam rantai makanan.

Penyebab utama logam berat menjadi bahan pencemar berbahaya yaitu karena logam berat tidak dapat dihancurkan oleh organisme hidup di lingkungan dan terakumulasi di lingkungan, terutama mengendap di dasar perairan. Biota air yang hidup dalam peraian tercemar logam berat dapat mengakumulasi logam berat tersebut dalam jaringan tubuhnya. makin tinggi kandungan logam dalam perairan akan semakin tinggi pula kandungan logam berat yang terakumulasi dalam tubuh hewan tersebut (Amin dan Nurrachmi, 2015).

Salah satu biota laut yang mampu mengakumulasikan bahan pencemar logam berat tersebut yaitu siput Ceritidea obtusa yang termasuk ke dalam filum moluska 
yang pada umumnya mencari makan dengan cara deposit feeder yaitu mengumpulkan partikel kecil berupa detritus berserta mikroorganisme terkecil yang mengendap didasar substrat, sehingga mampu mengakumulasikan bahan-bahan pencemar dengan jumlah besar, sifat biokumulatif ini yang menyebabkan organisme tersebut harus diwaspadai bila dikonsumsi secara terus menerus.

Berdasarkan uraian di atas maka penulis tertarik melakukan penelitian tentang analisis kandungan logam berat $\mathrm{Pb}$, $\mathrm{Cu}$ dan $\mathrm{Zn}$ yang terakumulasi pada siput sedut mata merah (C.obtusa) di Perairan Pulau Mendol Kecamatan Kuala Kampar.

\section{Tujuan dan Manfaat}

Adapun tujuan dari penelitian adalah sebagai berikut :

1. Untuk mengetahui perbedaan kandungan logam $\mathrm{Pb}, \mathrm{Cu}$ dan $\mathrm{Zn}$ antar stasiun pada siput sedut dan sedimen di Perairan Mendol.

2. Untuk mengetahui hubungan kandungan logam $\mathrm{Pb}, \mathrm{Cu}$ dan $\mathrm{Zn}$ pada siput sedut dengan sedimen di Perairan Mendol antar setasiun.

3. Untuk mengetahui batas aman konsumsi siput sedut di Perairan Mendol.

4. Untuk mengetahui tingkat pencemaran logam berat berdasarkan PTWI di Perairan Mendol.

Adapun manfaat dari penelitian ini adalah sebagai berikut :

1. Untuk memberikan informasi tentang besar kandungan logam $\mathrm{Pb}, \mathrm{Cu}$ dan $\mathrm{Zn}$ pada siput sedut dan sedimen di Perairan Mendol.

2. Untuk memberikan informasi tentang hubungan kandungan logam $\mathrm{Pb}, \mathrm{Cu}$ dan Zn pada siput sedut dan kandungan logam pada sedimen di Perairan Mendol.

\section{METODE PENELITIAN}

\section{Waktu dan Tempat}

Penelitian ini telah dilaksanakan pada bulan Juli 2018. Pengambilan sampel dilaksanakan di Perairan Pulau Mendol Kecamatan Kuala Kampar Kabupaten Pelalawan.

Analisis kandungan logam berat pada siput sedut dan sedimen dilakukan dengan menggunakan Atomic Absorption Spectrophotometer (AAS) di Laboratorium Kimia Laut Jurusan Ilmu Kelautan Fakultas Perikanan dan Kelautan Universitas Riau.

Metode yang digunakan dalam penelitian ini adalah metode survey Sampel siput dan sedimen diambil secara langsung pada siang hari dari setiap stasiun yang telah ditetapkan.

\section{Penentuan Lokasi Titik Sampling}

Lokasi pengambilan sampel ditentukan menggunakan purposive sampling stasiun pada penelitian ini ditetapkan atas 3 yakni: Stasiun I terletak di daerah mangrove dekat pemukiman warga, Stasiun 2 sekitar pelabuhan dan Stasiun 3 kawasan hutan mangrove. 


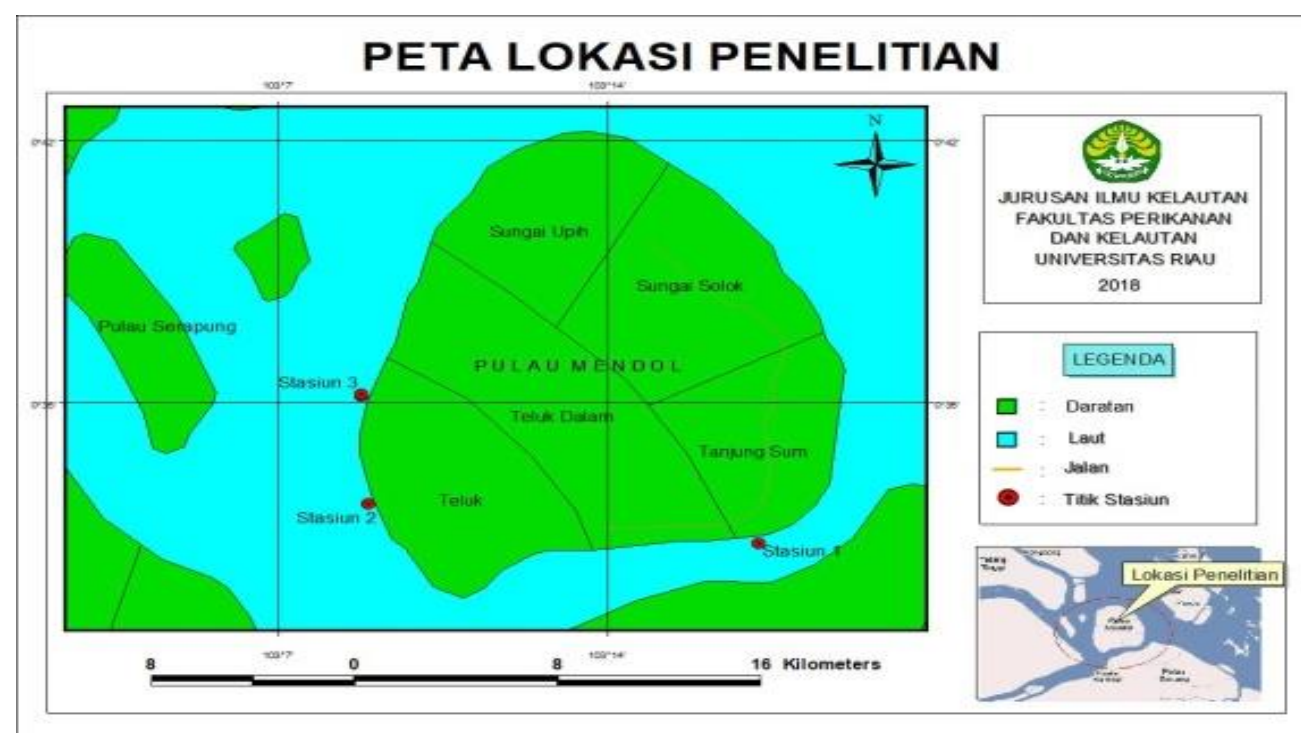

\section{Pengukuran Parameter Kualitas Air}

Pengukuran parameter kualitas perairan dilakukan di masing-masing stasiun saat pengambilan sampel siput. Pengukuran ini bertujuan untuk menggambarkan kondisi perairan pada saat penelitian. Beberapa parameter kualitas air yang diukur adalah suhu, $\mathrm{pH}$, dan salinitas

\section{Pengambilan dan Penanganan Sampel}

Pengambilan sampel dilakukan di kawasan Perairan Mendol secara langsung dengan menggunakan tangan di setiap stasiun ketika surut, kemudian sampel dicuci bersih dan dimasukkan ke dalam kontong plastik dan diberi label berdasarkan stasiunnya. Sampel sedimen diambil di sekitar keberadaan siput sedut pada bagian permukaan $(0-5 \mathrm{~cm})$ diambil secara langsung dengan menggunakan spatula. Masukan kedalam kantong plastic setelah itu sampel siput sedut dan sedimen dimasukkan ke dalam ice box, dibawa ke laboratorium untuk diidentifikasi dan dianalisis.

Prosedur analisis kandungan logam berat pada sedimen dilakukan dengan metode kering berdasarkan prosedur Yap et al. (2003). Sebagai berikut:

Sampel sedimen diambil sebanyak 50 gram kemudian dikeringkan dalam oven pada suhu $80^{\circ} \mathrm{C}$ sampai dicapai berat konstan. Sampel sedimen yang telah kering digerus dengan menggunakan penumbuk (mortar).

Setelah itu sampel ditimbang sebanyak 1 gram untuk didestruksi dalam kombinasi larutan $\mathrm{HNO}_{3}$ dan $\mathrm{HCLO}_{4}$ dengan perbandingan 4:1, menggunakan block digester $40^{\circ} \mathrm{C}$ selama 1 jam dan kemudian suhu dinaikkan menjadi $140^{\circ} \mathrm{C}$ selama 3 jam.

Setelah sampel sedimen terdestruksi, larutan tersebut didinginkan dan diencerkan dengan menggunakan aquades menjadi $40 \mathrm{ml}$ dan disaring dengan kertas saring Whattman no. 63 (untuk menghindari penyumbatan pipa kapiler pada saat analisis sampel dengan (AAS) dan disimpan dalam botol sampel. Selanjutnya larutan sampel tersebut dianalisis kandungan logam beratnya dengan AAS.

\section{Analisis Logam Berat}

Analisis konsentrasi logam berat pada siput dilakukan dengan metode kering berdasarkan prosedur Yap et al., (2003). Analisis konsentrasi logam berat pada siput sedut dilakukan dengan beberapa tahap kerja yaitu :

1. Penghancuran (Destruksi)

2. Penyaringan

3. Pengujian Larutan Blanko 
4. Pembuatan Larutan Standar

5. Pemeriksaan dengan AAS

6.Perhitungan Kandungan Logam berat

Kandungan logam berat pada sampel dihitung menggunakan rumus menurut Razak (1987) yaitu sebagai berikut

$$
K=\frac{(D \times B)}{A}
$$

Keterangan :

$\mathrm{K}$ : Konsentrasi yang sebenarnya dari sampel $(\mu \mathrm{g} / \mathrm{g})$

D: Kandungan yang dihitung berdasarkan nilai absorbansi $(\mu \mathrm{g} / \mathrm{ml})$

B : Volume sampel (ml)

A : Berat sampel $(\mathrm{g})$

Hasil perhitungan konsentrasi logam berat berdasarkan rumus tersebut kemudian dibandingkan dengan baku mutu logam terlarut yang masih diizinkan dalam perairan sesuai dengan peruntukannya, yaitu berdasarkan Kepmen LH No 51 Tahun 2004.

\section{Analisis Data}

Data yang diperoleh ditabulasikan dalam bentuk tabel dan histogram, selanjutnya nilai konsentrasi logam berat pada siput sedut dan sedimen, kemudian dibahas secara deskriptif. Analisis dilakukan dengan menggunakan software Microsoft dan Statistical for Social Science (SPSS).

Untuk mengetahui hubungan antara konsentrasi logam berat pada siput sedut dan sedimen, digunakan hubungan korelasi dengan model matematis.

Keterangan :

$$
Y=a+b x
$$

$$
\begin{aligned}
& \text { Y : Konsentrasi logam berat } \\
& \text { Siput sedut } \\
& \text { X : Konsentrasi logam pada } \\
& \text { sedimen }
\end{aligned}
$$

Dimana digunakan determinasi $\left(\mathrm{R}^{2}\right)$ dan keeratan hubungannya akan digunakan koefisien korelasi ( $\mathrm{r}$ ) dengan nilai $\mathrm{r}$ berada antara 0-1. Kerataan ini menurut Tanjung (2014) adalah sebagai berikut:
a. 0,00-0,20: Hubungan sangat lemah
b. 0,21-0,40: Hubungan lemah
c. 0,41-0,70 : Hubungan sedang
d. 0,71-0,90 : Hubungan kuat
e. $0,91-1,00$ : Hubungan sangat kuat

\section{Batas Aman Konsumsi}

Menurut Badan Standardisasi Nasional (2009), penentuan batas aman konsumsi dilakukan dengan mengacu pada nilai PTWI (Provisional Tolerable Weekly Intake). The Joint FAO/WHO Expert Committee on Food Additives (2004) menyatakan bahwa PTWI tergantung pada jumlah, jangka waktu konsumsi dan tingkat kontaminasi makanan yang dikonsumsi oleh manusia dan dapat dihitung. Nilai PTWI untuk logam $\mathrm{Pb}$ per minggu setara dengan $1750 \mu \mathrm{g} / \mathrm{kg}$ untuk $70 \mathrm{Kg}$ berat badan orang dewasa. logam $\mathrm{Cu}$ setara dengan $245000 \mu \mathrm{g} / \mathrm{kg}$. Sedangkan logam Zn setara dengan $490000 \mu \mathrm{g} / \mathrm{kg}$.

Batas aman konsumsi siput $(\mathrm{kg} / \mathrm{minggu})=$ PTWI : K : 1000

\section{Keterangan:}

$$
\begin{array}{ll}
\mathrm{PTWI} & :(\mu \mathrm{g} / \mathrm{kg} / \mathrm{minggu}) \\
\mathrm{K} & : \text { Kandungan logam } \\
& \text { pada sampel } \\
1000 & : \text { Konversi dari g ke kg }
\end{array}
$$

\section{Penentuan Status Pencemaran Logam Berat}

Penentuan status pencemaran logam berat pada masing-masing stasiun dilakukan menurut rumus yang dipakai oleh Usero et al. (1997) yaitu sebagai berikut:

$$
\text { MPI }=\sqrt[n]{\mathrm{C} 1 \times \mathrm{C} 2 \times \mathrm{C} 3 \ldots \mathrm{Cn}}
$$

Keterangan : 
MPI : Metal Pollution Index

n : Jumlah jenis logam

Cn : Kandungan loga pada sampel.

Selanjutnya hasil perhitungan dengan MPI pada penelitian ini dibandingkan dengan nilai MPI pada lokasi penelitian lain yang memiliki karakter perairan hampir sama.

\section{HASIL DAN PEMBAHASAN}

\section{HASIL}

\section{Parameter Kualitas Perairan}

Parameter kualitas perairan di Pulau Mendol yang diukur adalah suhu, $\mathrm{pH}$, salinitas. Pengukuran dilakukan untuk mengetahui kondisi perairan pada lokasi penelitian. Dari hasil penelitian yang dilaksanakan didapatkan suhu perairan 28,3 ${ }^{\circ} \mathrm{C}$; pH 6,6; salinitas 30,3 ppt..

Tabel 1 .Rata-rata Parameter Kualitas Perairan

\begin{tabular}{ccccc} 
Stariun & Koordinat & $\begin{array}{c}\text { Suhu } \\
(\mathrm{C})\end{array}$ & $\mathrm{pH}$ & $\begin{array}{c}\text { Salinitas } \\
\text { (ppt) }\end{array}$ \\
\hline 1 & $\begin{array}{c}00^{0} 31^{\prime} 40.10^{\prime \prime} \mathrm{LU} \\
103^{0} 16^{\prime} 10.61^{\prime \prime} \mathrm{BT}\end{array}$ & 29 & 7 & 30 \\
2 & $\begin{array}{c}00^{0} 31^{\prime} 41.81^{\prime \prime} \mathrm{LU} \\
103^{0} 16^{\prime} 08.80^{\prime \prime} \mathrm{BT}\end{array}$ & 27 & 6 & 3.1 \\
3 & $\begin{array}{c}00^{0} 31^{\prime} 42.88^{\prime \prime} \mathrm{LU} \\
10^{0} 16^{\prime} 25.70^{\prime \prime} \mathrm{BT}\end{array}$ & 29 & 7 & 30 \\
\hline Rata-rata & & 28.3 & 6.6 & 30.3
\end{tabular}

\section{Kandungan logam $\mathrm{Pb}, \mathrm{Cu}$ dan $\mathrm{Zn}$ pada Siput Sedut}

Hasil penelitian ini menunjukkan nilai kandungan logam $\mathrm{Pb}, \mathrm{cu}$, dan zn pada siput sedut yg tertinggi pada stasiun 2, secara berurutan yaitu : 9,2633 $\mu \mathrm{g} / \mathrm{g}, 72,040$ $\mu \mathrm{g} / \mathrm{g}, \quad 111,748 \mu \mathrm{g} / \mathrm{g}$. Sedangkan untuk logam pb, cu,dan zn, pada sedimen yang tertinggi terdapat pada stasiun 2 yaitu: $23,990 \mu \mathrm{g} / \mathrm{g}, \quad 4,795 \mu \mathrm{g} / \mathrm{g}, \quad 48,587 \mu \mathrm{g} / \mathrm{g}$ dalam Tabel 2.
Tabel 2 . Kandungan logam $\mathrm{Pb}, \mathrm{Cu}$ dan $\mathrm{Zn}$ pada Siput Sedut

\begin{tabular}{cccc}
\hline \multirow{3}{*}{ Stasiun } & \multicolumn{3}{c}{$\begin{array}{c}\text { Konsentrasi } \\
\text { Logam }(\mu \mathrm{g} / \mathrm{g})\end{array}$} \\
\cline { 2 - 4 } & $\mathrm{Pb}$ & $\mathrm{Cu}$ & $\mathrm{Zn}$ \\
\hline 1 & $6,4367 \pm 0,2925$ & $67,8300 \pm 0,4300$ & $102,2167 \pm 0,0575$ \\
2 & $9,2633 \pm 0,1674$ & $72,0400 \pm 0,4927$ & $111,7483 \pm 0,1975$ \\
3 & $8,4850 \pm 0,5850$ & $55,9683 \pm 0,1725$ & $105,5333 \pm 0,1875$ \\
\hline \multirow{2}{*}{ Rata-rata } & $8.0616 \pm 0.3483$ & $65,2794 \pm 0.3650$ & $106,4994 \pm 3,4425$ \\
& & & \\
\hline
\end{tabular}

Perbandingan kandungan logam $\mathrm{Pb}$, $\mathrm{Cu}$ dan $\mathrm{Zn}$ pada siput sedut berdasarkan Stasiun pengambilan sampel dapat dilihat pada Gambar 1 :

Perbandingan kandungan logam $\mathrm{Pb}$, $\mathrm{Cu}$ dan $\mathrm{Cn}$ pada siput sedut berdasarkan stasiun pengambilan sampel dapat dilihat pada Gambar 2

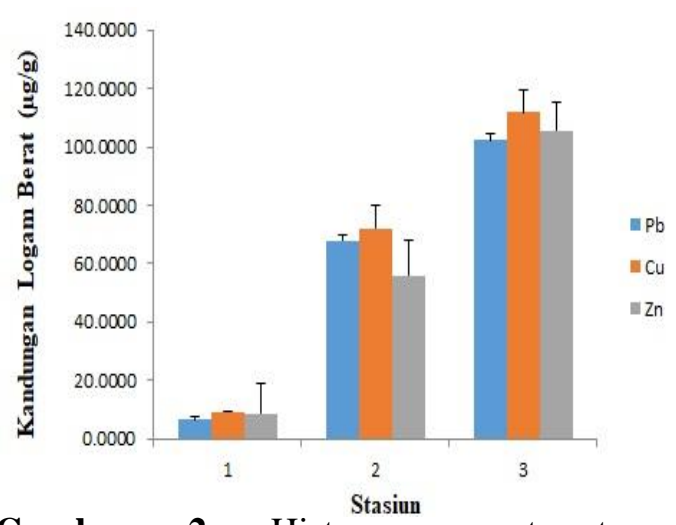

Gambar 2. Histrogram rata-rata kandungan logam $\mathrm{Pb}, \mathrm{Cu}$ dan $\mathrm{Zn}$ pada siput Sedut

Dari hasil grafik diketahui bahwa kandungan logam $\mathrm{Pb}$ dan $\mathrm{Cu}$ pada siput sedut memiliki nilai $\mathrm{p}<0,05$ yang berarti berbeda nyata sedangkan logam $\mathrm{Zn}$ memiliki nilai $p>0,05$ yang berarti tidak berbeda nyata, maka perlu dilakukan uji lanjut LSD untuk logam $\mathrm{Pb}$ dan $\mathrm{Cu}$. Hasil dari uji LSD untuk logam $\mathrm{Pb}$ menunjukkan antara Stasiun 2 dan 3 memiliki nilai $\mathrm{p}>0,05$ yang berarti tidak berbeda nyata, pada Stasiun 1 dan 3 memiliki nilai $p<0,05$ yang berarti berbeda nyata, sedangkan untuk Stasiun 1 
dan 2 memiliki nilai $\mathrm{p}<0,01$ yang berarti sangat berbeda nyata. Untuk hasil Uji LSD logam $\mathrm{Cu}$ pada siput sedut menunjukkan antara stasiun 2 dan 3 memiliki nilai $\mathrm{p}<$ 0,01 yang berarti sangat berbeda nyata, pada stasiun 1 dan 3 memiliki nilai $\mathrm{p}<$ 0,01 yang berarti sangat berbeda nyata, sedangkan untuk stasiun 1 dan 2 memiliki nilai $\mathrm{p}<0,01$ yang berarti sangat berbeda nyata.

Kandungan logam $\mathrm{Pb}, \mathrm{Cu}$ dan $\mathrm{Zn}$ pada Sedimen

Tabel 3. Rata-rata Logam Berat $\mathrm{Pb}, \mathrm{Cu}$ dan $\mathrm{Zn}$ pada Sedimen

\begin{tabular}{cccc}
\hline \multirow{3}{*}{ Stasiun } & \multicolumn{3}{c}{$\begin{array}{c}\text { Konsentrasi } \\
\text { Logam }(\mu g \mathrm{~g})\end{array}$} \\
\cline { 2 - 4 } & $\mathrm{Pb}$ & $\mathrm{Cu}$ & $\mathrm{Zn}$ \\
\hline 1 & $15,2100 \pm 1,7550$ & $3,3400 \pm 0,1700$ & $29,1217 \pm 1,7849$ \\
2 & $23,9900 \pm 0,5850$ & $4,7950 \pm 0,1472$ & $48,5867 \pm 8,9182$ \\
3 & $21,5500 \pm 3,4671$ & $4,5683 \pm 0,7279$ & $43,4567 \pm 15,1250$ \\
\hline Rata-rata & $20,2500 \pm 1,9357$ & $4,2344 \pm 0,3483$ & $40,3883 \pm 8,6093$
\end{tabular}

Kandungan logam $\mathrm{Pb}$ tertinggi pada sampel sedimen terdapat pada Stasiun 2 $(23,990 \mu \mathrm{g} / \mathrm{g})$ dan yang terendah terdapat pada stasiun $1 \quad(5,210 \mu \mathrm{g} / \mathrm{g})$. sedangkan logam $\mathrm{Cu}$ pada stasiun 2 dan 3 memiliki nilai yang hampir sama. Sedangkan $\mathrm{Pb}$ tertinggi pada stasiun $2(4,795 \mu \mathrm{g} / \mathrm{g})$ dan yang terendah terdapat pada stasiun 1 (3,340 $\mu \mathrm{g} / \mathrm{g})$. Logam $\mathrm{Zn}$ yang tertinggi terdapat pada stasiun $2(48,587 \mu \mathrm{g} / \mathrm{g})$ dan yang terendah terdapat pada stasiun 1 $(29,122 \mu \mathrm{g} / \mathrm{g})$.

Perbandingan kandungan logam $\mathrm{Pb}$, $\mathrm{Cu}$ dan $\mathrm{Zn}$ pada sampel sedimen dapat dilihat pada Gambar 3. Dari gambar berikut diketahui kandungan logam tertinggi sampai terendah berturut-turut adalah $\mathrm{Zn}>$ $\mathrm{Pb}>\mathrm{Cu}$.
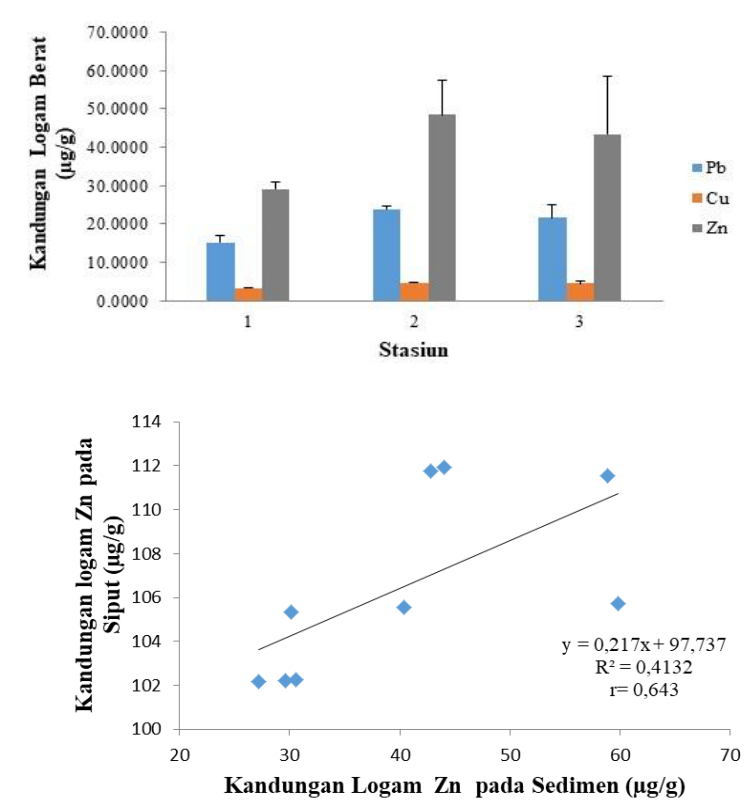

Gambar 3. Histrogram Rata-rata konsentrasi logam $\mathrm{Pb}, \mathrm{Cu}$ dan Zn pada Sedimen

\section{Hubungan Kandungan Logam $\mathrm{Pb}, \mathrm{Cu}$ dan Zn pada Siput Sedut dan kandungan Logam $\mathrm{Pb}, \mathrm{Cu}$ dan $\mathrm{Zn}$ pada Sedimen}

Berdasarkan hasil analisis regresi linear antara kandungan logam $\mathrm{Pb}$ pada daging siput dengan sedimen dapat dilihat pada Gambar 4 . nilai koefisien determinasi $\mathrm{R}^{2}=0,5943$ dan koerelasi koefisien korelasi $\mathrm{r}=0,7709$ dengan persamaan nilai Regresi $Y=0,2296+3,4135 x$.

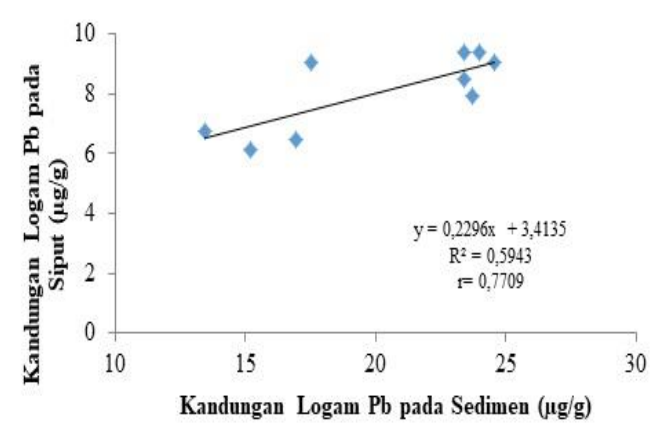

Gambar 4. Grafik Hubungan Kandungan Logam $\mathrm{Pb}$ pada Siput Sedut dengan Sedimen

Hasil analisis regresi linear antara kandungan logam $\mathrm{Cu}$ pada daging siput dapat dilihat pada Gambar 5. Nilai koefisien determinasi $\mathrm{R}^{2}=0,0331$ dan Koefisien 
korelasi $\mathrm{r}=0,182$ dengan persamaan nilai Regresi $Y=-432,15+2513,2 x$.

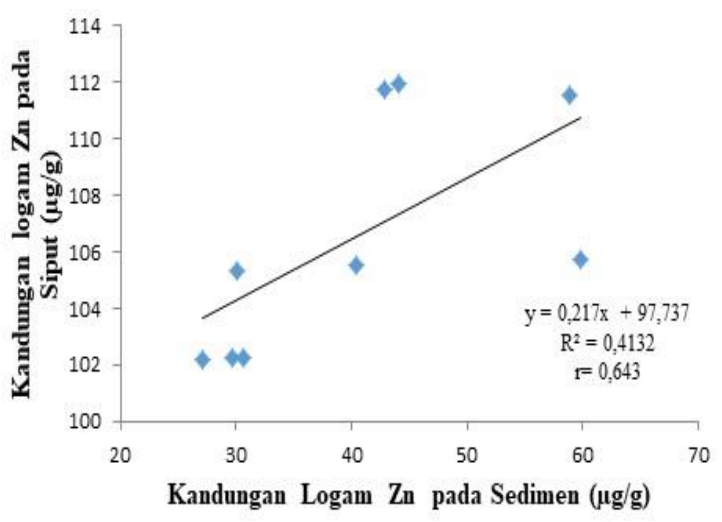

Gambar 5. Grafik Hubungan Kandungan Logam $\mathrm{Cu}$ padam Siput dengan Sedimen

Hasil analisis regresi linear antara kandungan logam $\mathrm{Zn}$ pada daging siput dapat dilihat pada Gambar 5. Nilai koefisien determinasi $\mathrm{R}^{2}=0,4132$ dan koerelasi koefisien korelasi $\mathrm{r}=0,643$ dengan persamaan nilai Regresi $\mathrm{Y}=0,217+$ $97,737 x$.

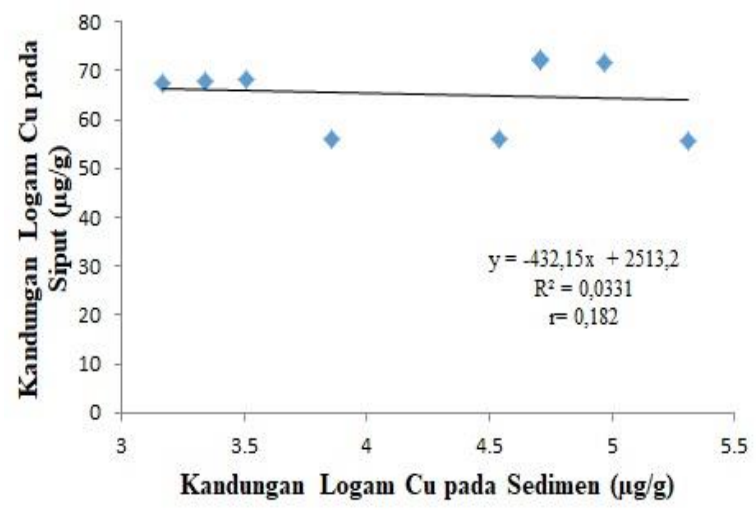

Gambar 5. Grafik Hubungan Kandungan Logam Zn pada Siput Sedut dengan Sedimen

Hasil analisis regresi linear antara kandungan logam $\mathrm{Zn}$ pada daging siput dapat dilihat pada Gambar 5. Nilai koefisien determinasi $\mathrm{R}^{2}=0,4132$ dan koerelasi koefisien korelasi $\mathrm{r}=0,643$ dengan persamaan nilai Regresi $\mathrm{Y}=0,217+$ $97,737 x .1$

\section{Batas Aman Konsumsi Siput Sedut di Perairan Mendol}

Berdasarkan hasil perhitungan batas aman konsumsi, maka diperoleh batas aman konsumsi siput sedut di stasiun 1 untuk logam $\mathrm{Pb}$ adalah $13,8121 \mathrm{~kg} / \mathrm{minggu}$, logam $\mathrm{Cu}$ adalah $180,1470 \mathrm{~kg} / \mathrm{minggu}$ dan logam $\mathrm{Zn}$ adalah 239,8081 kg/minggu. Sedangkan batas aman konsumsi siput sedut di Stasiun 2 untuk logam $\mathrm{Pb}$ adalah $14,1930 \mathrm{~kg} / \mathrm{minggu}$, logam $\mathrm{Cu}$ adalah $1,9870 \mathrm{~kg} / \mathrm{minggu}$ dan logam $\mathrm{Zn}$ adalah 219,0727 kg/minggu. Pada Stasiun 3 batas aman konsumsi siput diperoleh untuk logam $\mathrm{Pb}$ adalah 10,2941 kg/minggu, logam $\mathrm{Cu}$ adalah $218,750 \mathrm{~kg} / \mathrm{minggu}$ dan logam Zn adalah 230,0469 kg/minggu.

Tabel 4. Batas aman konsumsi $\mu \mathrm{g} / \mathrm{g}$ siput sedut di Perairan Mendol

\begin{tabular}{|c|c|c|c|c|}
\hline Stasiun & Logam & $\begin{array}{c}\text { Kandungan Logam } \\
\text { dalam Berat Basah } \\
(\mu \mathrm{g} / \mathrm{g})\end{array}$ & $\begin{array}{c}\text { Nilai PTWI } \\
\text { Perminggu untuk } \\
70 \mathrm{~kg} \text { Berat Tubuh } \\
(\mu \mathrm{g} / \mathrm{g})\end{array}$ & $\begin{array}{c}\text { Batas } \\
\text { Aman } \\
\text { Konsumsi }\end{array}$ \\
\hline \multirow{3}{*}{ Stasiun 1} & $\mathrm{~Pb}$ & 0,1267 & 1750 & 13,8121 \\
\hline & $\mathrm{Cu}$ & 1,3600 & 245000 & 180,1470 \\
\hline & $\mathrm{Zn}$ & 2,0433 & 490000 & 239,8081 \\
\hline \multirow{3}{*}{ Stasiun 2} & $\mathrm{~Pb}$ & 0,1233 & 1750 & 14,1930 \\
\hline & $\mathrm{Cu}$ & 1,4400 & 245000 & 1,9870 \\
\hline & $\mathrm{Zn}$ & 2,2367 & 490000 & 219,0727 \\
\hline \multirow{3}{*}{ Stasiun 3} & $\mathrm{~Pb}$ & 0,1700 & 1750 & 10,2941 \\
\hline & $\mathrm{Cu}$ & 1,1200 & 245000 & 218,750 \\
\hline & $\mathrm{Zn}$ & 2,110 & 490000 & 232,2274 \\
\hline \multirow[t]{3}{*}{ Rata-rata } & $\mathrm{Pb}$ & 0,1400 & 1750 & 12,500 \\
\hline & $\mathrm{Cu}$ & 1,3067 & 245000 & 18,7495 \\
\hline & $\mathrm{Zn}$ & 2,1300 & 490000 & 230,0469 \\
\hline
\end{tabular}

Berdasarkan hasil perhitungan batas aman konsumsi, maka diperoleh batas aman konsumsi siput sedut di stasiun 1 untuk logam $\mathrm{Pb}$ adalah $13,8121 \mathrm{~kg} / \mathrm{minggu}$, logam $\mathrm{Cu}$ adalah $180,1470 \mathrm{~kg} / \mathrm{minggu}$ dan logam $\mathrm{Zn}$ adalah 239,808 1kg/minggu. Sedangkan batas aman siput sedut di Stasiun 2 untuk logam $\mathrm{Pb}$ adalah $14,1930 \mathrm{~kg} / \mathrm{minggu}, \quad$ logam $\mathrm{Cu}$ adalah 1,9870 kg/minggu dan logam $\mathrm{Zn}$ adalah 219,0727 kg/minggu. Pada Stasiun 3 batas aman konsumsi siput sedut diperoleh untuk logam $\mathrm{Pb}$ adalah 10,2941 kg/minggu, 
logam $\mathrm{Cu}$ adalah $218,750 \mathrm{~kg} / \mathrm{minggu}$ dan logam $\mathrm{Zn}$ adalah $230,0469 \mathrm{~kg} / \mathrm{minggu}$.

\section{Status Pencemaran Logam Berat $\mathrm{Pb}, \mathrm{Cu}$ dan Zn Pada Siput di Sekitar Perairan Mendol}

Berdasarkan hasil perhitungan status pencemaran logam berat pada siput di Perairan Mendol dilakukan dengan rumus menurut Usero et al. (1997) yaitu rumus perhitungan metal pollution index (MPI) sebagai berikut:

$$
\begin{gathered}
\text { MPI }=\sqrt[3]{c 1 \times c 2 \times c 3} \\
=\sqrt[3]{8,0617 \times 65,2794 \times 40,3883} \\
=3,02
\end{gathered}
$$

Hasil perhitunggan menunjukan nilai MPI $\mathrm{Pb}, \mathrm{Cu}$ dan $\mathrm{Zn}$ adalah 3,02. Kandungan logam $\mathrm{Pb}, \mathrm{Cu}$ dan $\mathrm{Zn}$ pada sedimen masih jauh di bawah nilai ERL maupun ERM, yaitu pada logam $\mathrm{Pb}$ $20,2500 \mu \mathrm{g} / \mathrm{g}, \operatorname{logam} \mathrm{Cu} 4,2344 \mu \mathrm{g} / \mathrm{g}$ dan logam $\mathrm{Zn} 106,4994 \mu \mathrm{g} / \mathrm{g}$ yang berarti logam $\mathrm{Pb}, \mathrm{Cu}$ dan $\mathrm{Zn}$ di Perairan Pulau Mendol belum memberikan dampak negatif terhadap organisme yang ada di perairan tersebut (Tabel 5).

Tabel 5. Perbandingan Konsentrasi Logam Berat $(\mu \mathrm{g} / \mathrm{g})$ pada Sedimen di

\begin{tabular}{|c|c|c|c|}
\hline Logam & Konsentiasi Logam Pendititian (uge of & $\begin{array}{l}\mathbb{R} \\
(406)\end{array}$ & $\begin{array}{l}\text { ERV } \\
(489) \\
\end{array}$ \\
\hline ?f & 20,2500 & 46,70 & 28,800 \\
\hline Od & $4,2,244$ & 34,00 & 270,00 \\
\hline Zn & 105,1994 & 150,0 & 40,000 \\
\hline
\end{tabular}
Perairan Mendol dengan Nilai Standar ERL dan ERM

Menurut Standar Quality Guideline for Sediment untuk mengetahui tingkat kontaminasi yang terjadi diperairan Mendol maka konsentrasi logam berat pada sedimen tersebut dibandingkan dengan standar ERL dan ERM. Perbandingan konsentrasi logam $\mathrm{Pb}, \mathrm{Cu}$ dan $\mathrm{Zn}$ yang diperoleh selama penelitian adalah sebesar $20,2500 \mu \mathrm{g} / \mathrm{g}$ pada logam $\mathrm{Pb}$, untuk logam $\mathrm{Cu}$ sebesar 4,2344 $\mu \mathrm{g} / \mathrm{g}$ dan untuk logam $\mathrm{Zn}$ sebesar 106,4994 $\mu \mathrm{g} / \mathrm{g}$, yang menunjukkan logam $\mathrm{Pb}, \mathrm{Cu}$ dan $\mathrm{Zn}$ belum memberikan dampak negatif terhadap organisme yang ada diperairan uuPulau

Mendol.

Namun jika pada kandungan logam $\mathrm{Pb}, \mathrm{Cu}$ dan $\mathrm{Zn}$ pada sedimen di perairan ini masih dibawah baku mutu perairan perlu diperhatikan bahwa keberadaan logam berat dapat terakumulasi pada tubuh biota laut melalui proses rantai makanan maka sangat berbahaya jika biota tersebut dikonsumsi oleh manusia.

\section{KESIMPULAN DAN SARAN}

\section{Kesimpulan}

Kandungan logam $\mathrm{Pb}$ tertinggi terdapat pada Stasiun $2(8,4850 \mu \mathrm{g} / \mathrm{g})$ dan kandungan logam terendah terdapat pada stasiun $1(6,4367 \mu \mathrm{g} / \mathrm{g})$. Logam $\mathrm{Cu}$ yang tertinggi terdapat pada stasiun $2(72,040$ $\mu \mathrm{g} / \mathrm{g}$ ) dan kandungan logam terendah terdapat pada stasiun $3(55,968 \mu \mathrm{g} / \mathrm{g})$. Logam $\mathrm{Zn}$ yang tertinggi terdapat pada stasiun $2(111,748 \mu \mathrm{g} / \mathrm{g})$ dan yang terendah terdapat pada stasiun $1(102,216 \mu \mathrm{g} / \mathrm{g})$, hal ini diduga karena dipengaruhi oleh aktivitas sekitar pantai tempat penelitian dan kemampun siput sedut untuk mengakumulasi logam berat.

Berdasarkan Nilai MPI (Metal Pollution Index) yaitu 3,02 tergolong sangat jauh di bawah nilai ERI maupun ERM, yang berarti logam $\mathrm{Pb}, \mathrm{Cu}$ dan $\mathrm{Zn}$ di perairan Medol memberikan dampak negatif terhadap organisme yang ada di perairan tersebut.

Nilai PTWI, logam $\mathrm{Cu}$, Zn pada siput sedut sangat tinggi yang berasal dari perairan Mendol memiliki batas aman konsumsi yang lebih rendah dari pada $\mathrm{Pb}$, $\mathrm{Cu}$ dan $\mathrm{Zn}$ serta berdasarkan hasil perhitungan status pencemaran logam berat pada siput sedut di Perairan Mendol belum memberikan dampak negatif terhadap organisme yang ada di Perairan tersebut. 


\section{Saran}

Perlu dilakukan penelitian lanjutan untuk mengetahui kecepatan siput sedut dalam mengakumulasi logam berat, serta untuk mengetahui keakuratan data dan perlu juga untuk menganalisis logam berat lain untuk menggambarkan tingkat pencemaran logam berat di Perairan Mendol.

\section{DAFTAR PUSTAKA}

1. Amin, B., dan I. Nurrachmi. (2015). Siput Sedut (Cerithdiea Obtusa) Sebagai Biomonitor Logam Berat Di Perairan Pantai Sekitar Bekas Penambangan Timah Singkep, Kepulawan Riau. Prosiding Seminar Antarbangsa Ke 8 : Ekologi, Habitat Manusia dan Perubahan Persekitaran di Alam Melayu.

2. BAPPEDA (Badan Perencanaan dan Pembangunan Daerah). (2008). Penyusunan Rencana Induk Pengembangan Pariwisata Daerah Kabupaten Pelalawan. Kuala Kampar: BAPPEDA Kabupaten Pelalauan (Tidak dipublikasikan).

3. FAO/WHO (Food Agricultural Organization/ World Health Organization). (2002). Guidelines for The Evaluation of Probiotics in Food. Report of A Joint FAO/WHO Working Group on Drafting Guidelines for The Evaluation of Probiotics in Food Ontario. Canada.

4. Keputusan Menteri Lingkungan Hidup Nomor 51 Tahun 2004 Tentang Baku Mutu Air Laut.

5. Razak, H.(1987) Petunjuk Cara Pengambilan Contoh dan Metode Analisis Logam Berat. Jakarta LON-LIPI.

6. SNI (Standar Nasional Indonesia). (2009). Batas Maksimum Pencemara Logam Berat Dalam Pangan. Badan Standarisasi Nasional. Jakarta.

7. Tanjung, A. (2014). Rancangan Percobaan (Edisi Revisi) (P. 118). Tantaramesta. Bandung.

8. Usero, J., E. Gonzales-Regalado dan I. Gracia. (1997). Trace Metals in Bivalve Mollusks Ruditapes Decussatus and Ruditapes Philippinarum from The Atlantic Coast of Southern Spain. Environment International Volume 23 Pages 291-298.

9. Yap, C. K., A, Ismal dan S. G. Tan. (2003). Concentration of $\mathrm{Cu}, \mathrm{Pb}$ dan $\mathrm{Zn}$ in The Green-Lipped Mussel Verna Viridis (Linnaeus) From Peninsula Malaysia. Marine Pollution Bulletin. Volume 46 Pages 1035-1048. 